\title{
The Impact of Job Tension on Job Satisfaction: A Study on Executive Level Employees of the Apparel Industry in Anuradhapura District of Sri Lanka
}

\author{
K. H. V. P. Yasarathne ${ }^{1}$, H. M. Nishanthi ${ }^{2 *}$ and M. V. S. Mendis ${ }^{3}$ \\ 1,2,3 Department of Human Resources Management, Faculty of Commerce and \\ Management Studies, University of Kelaniya, Sri Lanka \\ ${ }^{1}$ vkumonline@gmail.com, ${ }^{2}$ menakahewawaduge@gmail.com, \\ ${ }^{3}$ virangisonali2@gmail.com \\ *https://orcid.org/0000-0001-8519-1501
}

\begin{abstract}
Apparel industry in Sri Lanka has become major contributor to Sri Lanka's economic development. Due to supply of low cost creative labour and organizational friendly government policies, many international apparel brands and apparel firms are outsourcing their manufacturing functions to Asian countries. Of those, Sri Lanka is a leading country where most apparel sector giants are interested to invest in. Further, in Sri Lankan context apparel sector is highly competitive as quite a number of big giants such as MAS Holdings, Brandix Apparel Lanka Ltd, Hela Clothing (Pvt) Ltd are operating in the market. Due to this high competitiveness in the industry, greater struggle is visible to attract and retain key talent. However, retaining talent has become difficult due to the job tension associated with high competitiveness. In the current study, the researchers attempt to investigate in depth the impact of job tension on job satisfaction of the executive level employees of the Apparel Industry, with special reference to Anuradhapura District.
\end{abstract}

The executive level employees in three leading garment manufacturing organizations in Sri Lanka were investigated through a sample of 100 employees. Simple random sampling method was used to select the representative sample. A self-administrated structured questionnaire was used to collect data. The correlation analysis and regression analysis were used to test the research hypotheses. The study confirmed that job tension is significantly correlated with employee job satisfaction. The findings of the study also indicated that there is a strong negative relationship between job tension and job satisfaction of executive level employees. This study directly provides a major theoretical contribution filling the gaps of former studies which were done on apparel sector. The findings and the recommendations of the current research directly addresses lot of practical issues related to job tension and job satisfaction faced by the apparel firms.

Keywords: Job tension, Job satisfaction, Apparel industry

\section{Introduction}

Human Resources have become an outstanding resource of today's modern business world. No company will able to achieve its goals and objectives without having motivated, committed workforce within the company. Therefore, keeping employees satisfied is a necessity for any organization. One of the most widely 
used definitions in organizational research is that of Locke (1976), who defines job satisfaction as "a pleasurable or positive emotional state resulting from the appraisal of one's job or job experiences" (p. 1304). Others have defined it as simply how content an individual is with his or her job; whether he or she likes the job or not. Hoppock (1935) defined job satisfaction as "any combination of psychological, physiological and environmental circumstances that cause a person truthfully to say I am satisfied with my job" (p. 47). Saari and Judge (2004) mentioned that job satisfaction is the predictor of withdrawal behaviours like turnover and absenteeism of the organization. Satisfied employees are more likely to experience high internal work motivation, to give high quality work performance and to have less absenteeism and turnover (Baghaei, 2011).

Beehr and Newman (1978, p. 02) defined job tension as "a situation arising from the reaction of people towards their tasks and results in changes that compel individuals to cope and adjust and disrupt their normal performance". When a person is confronted with a situation which poses a threat, and perceives that she or he does not have the capability or resources to handle the stressors, the imbalance that results at that point in time is termed as tension (Luthan, 2005). According to Richardson and Rothstein (2008) job tension is a state in which work-related factors affect employees to the degree that psychological condition deviates from usual performance of an individual.

Sri Lankan apparel industry is well reputed in the global context due to the reliability and quality maintenance of the manufacturers who follow ethical practices such as free of child labor, free of forced labor and eco-friendly international standards (Embuldeniya, 2015). According to the Board of Investment of Sri Lanka (2016), the apparel industry in Sri Lanka had a modest beginning in the 1960 s producing mainly textile and clothing for the local market under heavy protection. When considering the apparel industry in Sri Lankan context, the industry itself is having a huge competition. The firms' management is pushing the employees to achieve high end targets to get the maximum output from each of the employees in the intention of maximizing the profit. Therefore, the employees have to undergo lot of job tension. Having considered the evidence of the background, current study was conducted to assess the impact of the job tension on the job satisfaction on the executive level employees of the apparel industry of Anuradhapura district in Sri Lanka.

\section{Literature Review}

\section{Job Tension}

Selye (1956) first introduced the concept of stress in to the life science in 1936 . He defined stress as "The power, force, or burden exerted upon a physical object or person which resist these forces and attempt to maintain its original state." (Selye, 1956). Mark and Smith (2012) pointed out that occupational tension is a strong factor behind various diseases experienced by industrial workers. Job tension is identified by House and Rizzo (1972a) as the pressure that one is experiencing due to the job demands. This would result in feelings of stress or anxiety, or the satisfaction from leaving 
the work place (Taylor, 1953). Hence, job tension is noted to be co-exist with employee stress (Lazarus, 1996). Job tension not only hinders the mental wellness of the employee but might be the reason for the physical symptoms such as tiredness, irritation and digestive issues as well (House and Rizzo, 1972b). Hence, this study considers both mental health issues and physical stresses into consideration.

Starting a new job would likely to come with much tension if the employee is inexperienced, cannot cope with the workload, uncomfortable around their bosses or colleagues and not motivated by the work itself. On the other hand, if an employee is starting his or her career where they feel competent, supported by their colleagues and the management they would feel a very low level of job tension. Stress is often developed when an individual is assigned a major responsibility without proper authority and delegation of power. Within Sri Lankan context, Weerasuriya and Nishanthi (2014) found that there is an impact of supervisory leadership style on employee job related stress level in healthcare sector in Sri Lanka. Hence, interactions with leaders and their behaviors can also have an impact on job stress/ tension at work. Interpersonal factors such as group cohesiveness, functional dependence, communication frequency, relative authority and organizational distance between the role sender and the focal persons are important topics in organizational behavior (Brief, Schuler, \& Van Sell, 1981). According to Schermerhorn, Hunt, Osborn \& Uhl-Bien (2011) a list of common stressors includes the following:
- Task demands: Being asked to do too much or being asked to do too little

- Role ambiguities: not knowing what one is expected to do or how work performance is evaluated

- Role conflicts: feeling unable to satisfy multiple, possibly conflicting, performance expectations.

- Ethical dilemmas: Being asked to do things that violate the law or personal values.

- Interpersonal problems: Experiencing bad relationships or working with others who do not get along.

- Career developments: Moving too fast and feeling stretched; moving too slowly and feeling plateau.

- Physical setting: Being bothered by noise, lack of privacy, pollution, or other unpleasant working conditions

\section{Job Satisfaction}

Vroom (1964) defined job satisfaction as affective orientations on the part of individuals toward work roles which they are presently occupying. Weiss (2002) argued that conceptually job satisfaction is a wider construct which is concerned with all or most characteristics of the job and the working environment, within which the employees are rewarded, fulfilled and satisfied. The widely used definition on job satisfaction in organizational research is that of Locke (1976) who described job satisfaction as "a pleasurable or positive emotional state resulting from the appraisal of one's job or job experiences"(p. 1304). Herzberg 
(1968) in his findings revealed that certain characteristics of a job are consistently related to job satisfaction, while different factors are associated with job dissatisfaction.

Table 01: Herzberg's Motivation- Hygiene Theory

\begin{tabular}{|l|l|}
\hline Leading to dissatisfaction & \multicolumn{2}{|c|}{ Leading to satisfaction } \\
\hline - High job related tension & - Achievement \\
- Supervision & - Recognition \\
- Relationship with boss & - Work itself \\
- Work conditions & - Responsibility \\
- Salary & - Advancement \\
\hline
\end{tabular}

Source: Herzberg, (1968)

The conclusion he drew was that job satisfaction and job dissatisfaction are not opposites. The opposite of satisfaction is no satisfaction and further the opposite of dissatisfaction is no dissatisfaction.

Job satisfaction has been considered as one of the critical factors which affect the efficiency and effectiveness of organisations. As the current business context is dynamic employees should be treatedin a way that enhances their satisfaction of the job minimising any stressors. When analysing job satisfaction the logic is that a satisfied employee is a happy employee and a happy employee is a successful employee (Aziri, 2011). Though fear has been identified as a powerful motivator, its effect tends to last for very short period of time. As soon the threat is raised, the performance deteriorates. The positive motivators resulting job satisfaction which leads to benefits such as reduced grievances, absences, turnover, dismissals as well as improved attendance and positive work attitude (Kaliski, 2007) which might reduce job tension.
In general, job tension and job satisfaction are interrelated terms often used in the working environment. Cooper, Rout \& Faragher (1989) identified four factors affecting job tension which are predictive of job dissatisfaction. Vinokur- Kaplan (1991) stated that organization factors such as workload and working condition were negatively related with job satisfaction. Babajide \& Akintayo (2011) indicated that the pressure emanated from the job has considerably influenced the perceived level of job satisfaction. According to Koustelios, Theodorakis \& Goulimaris (2004) there is an inverse relationship between job tension and job satisfaction of physical education teachers in Greece. That study examines role conflict, role ambiguity, and job satisfaction among Greek physical education teachers, and the extent to which role conflict and role ambiguity predict job satisfaction. All members of the sample of 61 physical education teachers were employed in Greek "Sport for all" programs. The standard multiple regression analysis shows that role conflict and role ambiguity are significant predictors of job satisfaction. 
Based on the literature reviewed, following conceptual model is formulated to depict the relationship between job tension and job satisfaction
(Figure 1). The framework shows one independent variable which is job tension and one dependent variable which is job satisfaction.
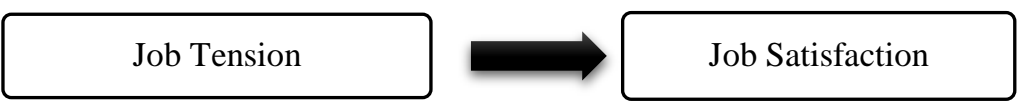

\section{Figure 01: Conceptual Framework}

Source: Authors, 2018

Based on the above conceptual model the following hypothesis has been formulated for this study.

$\mathbf{H}_{1}$ : There is a significant negative impact of job tension on job satisfaction.

\section{Research Methodology}

This study is a cross sectional study and explanatory in nature. The population of the study comprised of all the executive level employees in the apparel industry who are working in Anuradhapura district. By considering limited time period of research and geographical limitations, researcher decided only to take three apparel firms situated in Anuradhapura district. The researcher selected a sample of 100 employees and simple random sampling method was adopted. The primary data were collected through a structured self-administrated structured questionnaire. The scale items were adopted from job tension scale and overall job satisfaction scale. The job tension scale was developed by House and Rizzo (1972b). The overall job satisfaction measure was developed by Cammann, Fichman, Jenkins, and Klesh (1983) as part of the Michigan organizational assessment questionnaire (OAQ), uses three items to describe an employee's subjective response to working in his or her job and organization. This is a global indication of worker satisfaction with a job.

The scale items were adopted from a binary scale format for the independent variable which is job tension and seven point Likert scale was used to measure job satisfaction. To avoid certain difficulties faced in analysing the data, the researchers assumed a three scale format for the independent variable which made all of the independent and dependent variable continuous for statistical data analysis. Analysis was done through the use of SPSS package 20.0 version. Hypothesis of the study was measured through Pearson product moment correlation and regression analysis and reliability of the instruments used to collect data were assessed using relevant techniques. Researchers used charts, tables and figures to present data.

\section{Analysis and Results}

\section{Reliability Test and Scatter Plot}

The reliability of a measure indicates the extent to which it is without bias (error free) and hence ensures consistent measurement across time and across the various items in the instrument (Sekaran, 
2006). In other words, the reliability of a measure is an indication of the stability and consistency with which the instrument measures the concept and helps to assess the "goodness" of a measure (Sekaran, 2006). This can be tested statistically by using Cronbach's alpha. According to Cronbach's alpha values presented in Table 2, it is visible that both scale items are of high reliability as they are above 0.7 .

Table 2: Reliability Statistics

\begin{tabular}{|c|c|}
\hline Construct & Cronbach's Alpha \\
\hline Job Tension & 0.831 \\
Job Satisfaction & 0.772 \\
\hline
\end{tabular}

Source: Survey data

To examine the relationship between independent variable and the dependent variable namely job tension and job satisfaction, scatter plots were constructed. Following graph shows the linearity between job tension and job satisfaction.

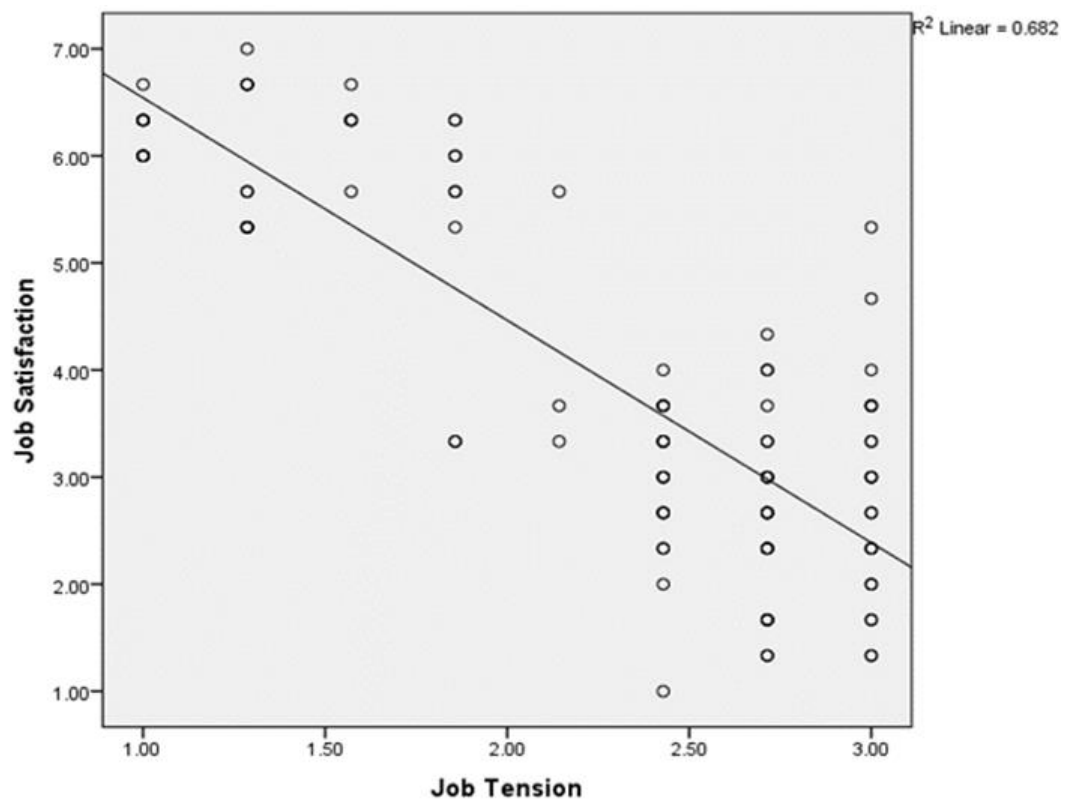

Figure 02: The Scatter Plot

Source: Survey Data, 2018 
As the relationship is linear, the Pearson's product - moment correlation coefficient was used to determine the relationship between job tension \& the job satisfaction which presented in the
Table 3 below. The desired level of significance is below 0.05. As these hypothesis directional, one-tailed test was used.

Table 03: Pearson's product - moment correlation for the independent variable and dependent variable

\begin{tabular}{|c|c|c|}
\hline Independent Variable & $\begin{array}{c}\text { Dependent Variable } \\
\text { ( Job satisfaction) }\end{array}$ & Sig. \\
\hline Job Tension & $-0.826^{* *}$ & 0.000 \\
\hline
\end{tabular}

**.Correlation is significant at the 0.01 level (1-tailed)

Source: Survey Data, 2018

The result indicates a strong negative correlation between job tension and job

\section{Hypothesis Testing}

To identify the impact of job tension on the job satisfaction, a regression analysis was carried out. The result of regression analysis on the independent variable satisfaction $(r=-0.826)$ at a significance level of 0.01 .

Table 4: Model Summary statistics on regression analysis

\begin{tabular}{|c|c|c|c|c|}
\hline Model & $\mathrm{R}$ & R Square & Adjusted R Square & $\begin{array}{c}\text { Std. Error of the } \\
\text { Estimate }\end{array}$ \\
\hline 1 & $-.826^{\mathrm{a}}$ & .682 & .679 & .96720 \\
\hline
\end{tabular}

a. Predictors: (Constant), Job Tension

Source: Survey Data, 2018

According to Table 04, $\mathrm{R}$ value represents Pearson's product - moment correlation of -0.826 which indicates a high degree of negative correlation. The $\mathrm{R}^{2}$ value indicates how much of the total variation in the dependent variable employee satisfaction can be explained by the independent variable, job tension. In this case, $68 \%$ variance in job against the dependent variable employees' job satisfaction is shown in the Table 4. satisfaction is explained through job tension, which is a strong impact. Thus, $\mathrm{H}_{1}$ is accepted. So, it could be statistically concluded that there is a significant negative impact of job tension on job satisfaction. 


\section{Discussion}

The current research is very important to the apparel industry in Sri Lanka as the apparel industry plays a major role in economic development of the country. In this research, the researchers have identified job tension as a key root cause which affects the level of job satisfaction. According to the calculated regression analysis $68 \%$ variance in job satisfaction is caused through job tension. It is clear that there is a strong negative impact of job tension on the job satisfaction. Further, Pearson's correlation coefficient is -0.826 with a 0.01 significance level showing that there is a strong negative correlation association between job tension and job satisfaction. Thus, $\mathrm{H}_{1}$ is accepted. Hence, it could be statistically concluded that there is a significant negative impact of job tension on the job satisfaction of executive level employees in the garment industry in Anuradhapura District.

Several recommendations can be made based on survey results. The finding of the research was that, there is a strong impact of job related tension and employee job satisfaction among the executive level employees of the apparel industry in Anuradhapura district of Sri Lanka. Hence, this finding can be used to enhance the employee satisfaction by minimizing the job related tension of the employees. Job related tension can be an outcome of heavy workload, not having enough skills and capabilities to accomplish the duties and the responsibilities of the job, having high end targets with the limited time and also the constant pressure applied by the management agendas. To minimize the job related tension, the management has to closely consider the above mentioned facts.

Also the management can take actions to implement awareness programs and technical training programs which will decrease the job related tension faced by the employees. This will enhance the job satisfaction increasing the productivity and the loyalty of the employees. In this research the researchers identified that there is a strong impact of job tension on the job satisfaction. Hence, job related tension can be considered as a root cause affecting the job satisfaction. When collecting data from the questionnaires, the researchers got the opportunity to speak to related sample units and researchers identified that constant management pressure applied to the employees have a huge impact on the job related tension. Implementing a proper HR system with a good system of grievance handling can minimize the job related tension of the employees which will increase the job satisfaction of the employees. Conducting workshops, implementing proper orientation programs and recruiting the correct person to the exact job position could be recommended as a solution to the rising job related tension of the employees in the apparel sector.

\section{Conclusion}

The main objective of this study was to understand the relationship between job tension and job satisfaction of executive level employees of the apparel industry in Anuradhapura District of Sri Lanka. The results of the research depict that job tension is a key root cause which affects the job satisfaction of the executive level employees of the apparel industry in Anuradhapura district hence it can be concluded that job tension has a heavy 
impact on the job satisfaction \& by controlling the job tension, job satisfaction can be enhanced which will ultimately lead to the overall performance enhancement.

\section{References}

Aziri, B. (2011). Job satisfaction: A literature review. Management Research and Practice, 3(4), 77-86.

Babajide, E. O., \& Akintayo, I. (2011). Occupational stress, psychological well-being and workers' behavior in manufacturing industries in south-west Nigeria. International Journal of Management and Innovation, 3(1), 32.

Baghaei, R. (2011). A comparative study of human resource management practices in private and public hospitals of Iran with special reference to job satisfaction of nurses. University of Pune.

Beehr, T.A., Newman, J.E. (1978), Job stress, employee health, and organizational effectiveness: A facet analysis, model, and literature review. Personnel Psychology, 31(4), 665-699.

Board of Investment of Sri Lanka (2016). Retrieved from http://www.investsrilanka.com/

Brief, A. P., Schuler, R. S., \& Van Sell, M. (1981). Managing job stress. Little, Brown.

Caplan, R. D., \& Jones, K. W. (1975). Effects of work load, role ambiguity, and type a personality on anxiety, depression, and heart rate. Journal of applied psychology, 60(6), 713.

Cammann, C., Fichman, M., Jenkins, G. D., Jr., \& Klesh, J. R. (1983). Assessing the attitudes and perceptions of organizational members. In S. E. Seashore, E. E. Lawler III, P. H. Mirvis, \& C. Cammann (Ed.), assessing organizational change: A guide to methods, measures, and practices (pp. 71-138). New York: Wiley.

Cooper, C. L., Rout, U., \& Faragher, B. (1989). Mental health, job satisfaction, and job stress among general practitioners. Bmj, 298(6670), 366-370.

Embuldeniya, A. 2015. Impact of Apparel Industry on the Economy of Sri Lanka. "Social Statistics", Journal of Social Statistics, 02(01): 01-14. Department of Economics, University of Kelaniya, Sri Lanka.

Herzberg, F. (1968). One more time: How do you motivate employees? Havard Business Review

Hoppock, R. (1935).Job satisfaction.New York: Harper and Brothers. 
House, R. J., \& Rizzo, J. R. (1972b). Toward the measurement of organizational practices: Scale development and validation. Journal of Applied Psychology, 56(5), 388-396.

House, R. J., \& Rizzo, J. R. (1972a). Role conflict and ambiguity as critical variables in a model of organizational behavior. Organizational behavior and human performance, 7(3), 467-505.

Pfeffer, P. (1992), Managing with power, Harvard business school press, Boston, 1992,30

Kaliski, B. S. (2007). Encyclopedia of Business and Finance. Detroit: Thomson gale.

Kabir, M. N., \& Parvin, M. M. (2011). Factors affecting employee job satisfaction of pharmaceutical sector. Australian Journal of Business and Management Research, 1(9), 113-123.

Lazarus, R.S. (1966), Psychological Stress and the Coping Process, McGraw Hill, New York, NY.

Locke, E. A. (1976). The nature and causes of job satisfaction. Handbook of industrial and organizational psychology, 1, 1297-1343.

Levi, L. (1998). Preface: Stress in Organizations-Theoretical and empirical approaches. Theories of Organizational Stress, Oxford University Press, New York, NY.

Luthan, Fred (2003), Organizational Behavior, M Grawhill pub. Ed 2003, 482

Koustelios, A., Theodorakis, N., \& Goulimaris, D. (2004). Role ambiguity, role conflict and job satisfaction among physical education teachers in Greece. International Journal of Educational Management, 18(2), 87-92.

Mark, G., \& Smith, A. P. (2012). Occupational stress, job characteristics, coping, and the mental health of nurses. British journal of health psychology, 17(3), 505521.

Richardson, K. M., \& Rothstein, H. R. (2008). Effects of occupational stress management intervention programs: A meta-analysis. Journal of Occupational Health Psychology, 13(1), 69-93.

Robert, K. Marie, M \& Mark, M (2009) Health and Safety Executive Management Standards and stress-related work outcomes, occupational medicine, 59(1), 574-579.

Saari, L. M., \& Judge, T. A. (2004). Employee attitudes and job satisfaction. Human Resource Management, 43(4), 395-407.

Schermerhorn, J. R., J. J. G. Hunt., R. N. Osborn \& M. Uhl-Bien, (2011), Organizational Behavior, John Wiley \& Sons, Inc. 
Sekaran, U. (2006). Research methods for business: A skill building approach. New York: John Wiley \& Sons.

Selye H, (1975): Stress without Distress, JP Lippicott Company New York.

Singh, N. (2001). Organisational Behaviour: Concepts, Theory and Practices: Managing People and Organisations in the 21st Century. Deep and Deep Publications.

Spector, P. E. (1997). Job satisfaction: Application, assessment, causes, and consequences. Thousand Oaks: Sage.

Rice, B., Knox, K., Rice, J., Martin, N., Fieger, P., \& Fitzgerald, A. (2017). Loyal employees in difficult settings: The compounding effects of inter-professional dysfunction and employee loyalty on job tension. Personnel Review, 46(8), 1755-1769.

Taylor, J. A. (1953). A personality scale of manifest anxiety. The Journal of abnormal and social psychology, 48(2), 285.

Vinokur-Kaplan, D. (1991). Job satisfaction among social workers in public and voluntary child welfare agencies. Child Welfare: Journal of Policy, Practice, and Program.

Vroom, V. (1964). Work and Motivation. New York: John Wiley \& Sons.

Weiss, H. M. (2002). Deconstructing job satisfaction: Separating evaluations, beliefs and affective experiences. Human Resource Management Review, 12(2), 173194.

Weerasuriya, M. K., \& Nishanthi, H. M. (2014). Impact of Supervisory Leadership Style on Employee Level of Stress in Sri Lankan Healthcare Sector, In: Proceedings of the 5th International Conference on Business and Information, University of Kelaniya, pp 143-152. 